J. Lake Sci.(湖泊科学), 2020, 32(2): 564-572

DOI 10. 18307/2020. 0226

(c) 2020 by Journal of Lake Sciences

\title{
三峡工程运用后坝下游河道泥沙输移变化规律”
}

\author{
郭小虎**,渠 庚,刘 亚,刘心愿 \\ (长江科学院水利部江湖治理与防洪重点实验室,武汉 430010)
}

\begin{abstract}
摘 要: 三峡工程蓄水后 “清水”下泄, 坝下游河段将会长期处于严重不饱和状态, 水流含沙量沿程恢复将会引起坝下游 长距离冲刷, 本文根据三峡工程蓄水前、后的实测资料分析了坝下游河道泥沙输移变化规律, 探索不同粒径组沙量沿程 恢复对河床冲刷的影响, 得到以下结论: 在蓄水初期 $\mathrm{d} \leqslant 0.031 \mathrm{~mm}$ 沙量恢复主要受河床补给与江湖人汇共同的影响,随着 水库下泄该粒径组沙量递减,使得各站该粒径组年均输沙量均远小于蓄水前的水平, 沙量恢复仍主要受河床补给与江湖 人汇的影响, 这是造成坝下游河道发生长距离冲刷的主要原因之一; 在蓄水初期 $0.031 \mathrm{~mm}<\mathrm{d} \leqslant 0.125 \mathrm{~mm}$ 沙量恢复主要受 河床补给的影响, 但江湖人汇的影响较大, 随着河床补给量逐渐减少, 各站该粒径组年均输沙量均小于蓄水前的水平, 沙 量恢复仍主要受河床补给的影响, 江湖人汇的影响逐渐减小, 这也是坝下游河道发生长距离冲刷的主要原因之一; $\mathrm{d}>$ $0.125 \mathrm{~mm}$ 沙量恢复主要受河床补给的影响, 蓄水初期该粒径组沙量在宜昌一监利河段沿程恢复速率较快, 且在监利站达 到蓄水前的水平, 随着时间推移, 在宜昌一监利河段沿程恢复且速率仍较快, 在监利站达到最大值, 其数值逐渐小于蓄水 前的水平,这是造成坝下游河道冲刷重点集中在宜昌一监利河段的主要原因.
\end{abstract}

关键词: 三峡工程;水库下游; 不同粒径组;泥沙输移

\section{Sediment transport of different particle size groups in the downstream channel after oper- ation of the Three Gorges Project *}

\author{
GUO Xiaohu** , QU Geng, LIU Ya \& LIU Xinyuan \\ ( Key Laboratory of River Regulation and Flood Control of MWR, Yangtze River Scientific Research Institute, Wuhan 430010, \\ P.R.China)
}

\begin{abstract}
Sediment concentrations in the downstream would be unsaturated in a serious long-term after the operation of the Three Gorges Project, since sediment concentration recovery causes long distance erosion in middle reach of the Yangtze River. Based on the field data collected after the operation of the Three Gorges Project, the sediment transport patterns in middle reach of the Yangtze River was analyzed, and the influence of sediment recovery along the river bed with different particle size groups on river bed erosion was explored. Result showed that: the recovery of sand content of $d \leqslant 0.031 \mathrm{~mm}$ was mainly affected by the replenishment of riverbeds and the inflow of rivers and lakes in the early stage of water storage. With the decrease of the amount of sand with $d \leqslant$ $0.031 \mathrm{~mm}$, the average annual sediment transport amount of that group at each station was much smaller than that before the water storage. Recovery was still mainly affected by riverbed recharge and inflow of rivers and lakes, which was one of the main causes of long-distance erosion in the downstream channel of the dam. In the early stage of water storage, the recovery of sand volume of $0.031 \mathrm{~mm}<\mathrm{d} \leqslant 0.125 \mathrm{~mm}$ was mainly affected by riverbed recharge, but the impact of rivers and lakes was significant. With the gradual reduction of riverbed recharge, the average annual sediment transport of the particle size $0.031 \mathrm{~mm}<\mathrm{d} \leqslant 0.125 \mathrm{~mm}$ at each station was lower than that before the water storage, and the sand recovery was still mainly affected by riverbed recharge. The influence of inflow from rivers and lakes is gradually reduced, though this is still one of the main reasons for the long-distance erosion of the river downstream of the dam. $d>0.125 \mathrm{~mm}$ sand recovery was mainly affected by riverbed recharge, in the initial stage of water storage, the sand content of this particle size group was faster in the Yichang-Jianli section, and it reached the level before the wa-
\end{abstract}

* 2019-03-29 收稿;2019-08-08 收修改稿.

科技部重点研发专项 (2016YFC0402303)、国家自然科学基金项目 (51339001，51409017)、三峡水库科学调度关键 技术第二阶段研究项目 (SXSN14385) 和财政部项目(12610100000018J129-5) 联合资助.

** 通信作者;E-mail:xiaohu001328@163.com. 
ter storage in Jianli Station. In the Yichang- Jianli section, the rate was still relatively fast as time passes, peaking at Jianli Station. The value was smaller than the level before the water storage. This was the main reason that the downstream river channel erosion was concentrated in the Yichang- Jianli River section.

Keywords: Three Gorges Project; downstream of reservoir; different particle size group ; sediment transport

三峡坝下游宜昌至大通干流河段长约 $1183 \mathrm{~km}$, 其中宜昌至枝城河段长约 $60.8 \mathrm{~km}$, 属山区性河道向冲 积平原河道过渡的弯曲型河道, 右岸有清江人汇; 枝城至城陵矶河段全长约 $347.2 \mathrm{~km}$, 左岸有沮漳河人汇, 右岸有松滋口、太平口、藕池口和调弦口 (1958 年冬封堵) 分流人洞庭湖,与洞庭湖水系 (湘、资、沅、澧“四 水”) 在湖区调蓄后从城陵矶出口重新汇人长江; 城陵矶至湖口河段长约 $547 \mathrm{~km}$, 有汉江、鄱阳湖水系及其他 支流人汇, 两岸分布有对河势起控制作用的天然山矶节点; 湖口至大通河段长约 $228 \mathrm{~km}$, 大通站受潮汐影响 不大 (图 1). 三峡工程蓄水运用后, 水库拦截大量泥沙, “清水”下泄,坝下游河段水流含沙量沿程恢复, 从而 引起坝下游长距离、长历时的河床冲淤调整,这种变化对坝下游防洪、水资源利用、水环境生态以及经济与 社会可持续发展等可能带来一定的影响, 因此开展三峡工程坝下游河道泥沙输移变化规律研究是十分必 要的.

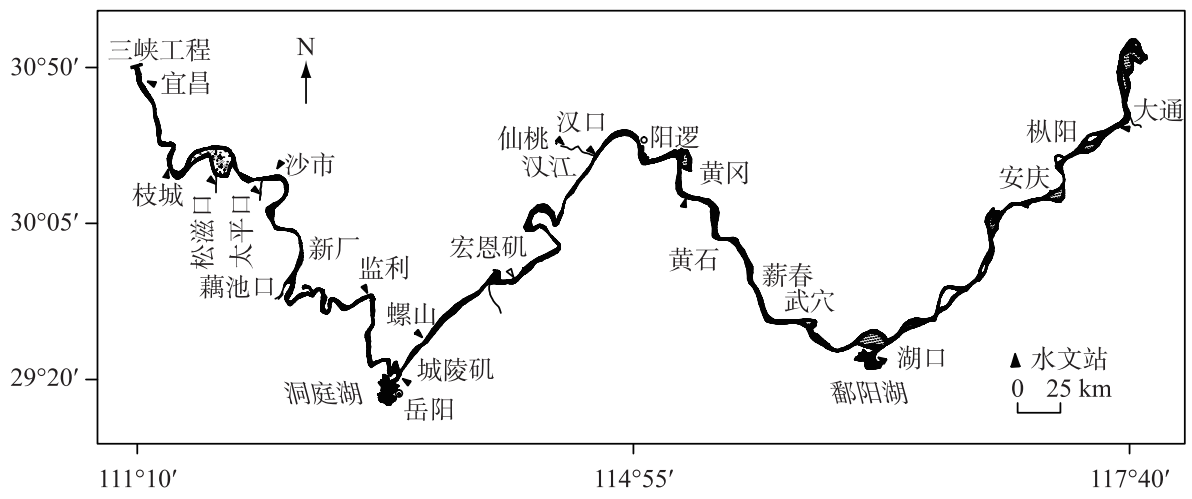

图 1 宜昌至大通河段示意图

Fig.1 Sketch map of the reach from Yichang to Datong section

目前关于水库下游泥沙输移特性的认识多源于对已建水库下游冲刷发展现象的分析. 文献 ${ }^{[1-7]}$ 显示, 水 库下游河床冲刷发展程度与距坝里程、流量、冲刷历时、分汇流及河床边界条件 (河床组成、河床比降等) 密 切相关. 根据丹江口水库下游资料分析, 认为水库下游存在 “淤粗悬细” 的现象, 发现襄阳以下河段存在细颗 粒冲刷同时粗颗粒淤积的粗细交换现象,并指出形成水库下游长距离冲刷的最根本原因是床沙级配沿程变 细以及冲刷过程中上段输送的悬移质中的粗颗粒与床沙中的细颗粒发生交换 ${ }^{[8]}$; 但丹江口建库后下游特定 河段存在分界粒径, 且不同河段分界粒径不同,粗沙淤积在一定河道边界条件下才会发生 ${ }^{[9]}$; 黄河三门峡水 库运用后坝下游细泥沙恢复量小且速率慢, 恢复的距离长; 中、粗泥沙恢复快, 恢复的距离短, 这种变化主要 与河床组成密切相关 ${ }^{[10]}$. 三峡工程蓄水初期坝下游细颗粒泥沙长距离冲刷的主要原因是补给严重不足, 粗 颗粒泥沙的冲淤特点与其上游河段能否补给充足密切相关 ${ }^{[11]}$. 三峡工程 2003-2011 年蓄水期间, $\mathrm{d}<0.125$ $\mathrm{mm}$ 粒径沙量在长江中游沿程缓慢恢复且恢复程度远小于蓄水前, 这是坝下游河段发生长距离冲刷的根本 原因; 而 $\mathrm{d}>0.125 \mathrm{~mm}$ 粒径沙量在宜昌一监利河段恢复速率较快, 且在监利站附近该粒径沙量基本恢复饱和, 这也造成了冲刷重点集中在荆江河段 ${ }^{[12]}$; 根据 1987-2014 年原型观测数据分析认为, 三峡水库蓄水后坝下 游 $\mathrm{d}<0.125 \mathrm{~mm}$ 各粒径组沙量沿程递增, 并小于蓄水前均值; $\mathrm{d}>0.125 \mathrm{~mm}$ 沙量在宜昌一监利河段得到补给, 其下游为淤积趋势 ${ }^{[13]}$. 以上成果均较好地分析了水库下游泥沙输移变化的规律, 但由于长江中下游江湖人 汇众多, 影响因素复杂, 本文采用最新的实测资料进一步深人分析了三峡工程运用后坝下游河段泥沙输移 变化规律, 探索不同粒径组沙量沿程恢复对河床冲刷的影响. 该成果不仅丰富水库下游不平衡输沙基本理 论,而且可为长江中下游江湖规划、治理及河道冲淤计算等提供技术支撑. 


\section{1 水库下泄水沙变化}

下面以宜昌水文站 60 多年实测的年径流量和年输沙量数据为代表, 分析三峡工程运用前、后的水沙变 化. 该站年径流量无明显变化趋势, 较之蓄水前, 三峡工程蓄水后年均径流量减少了约 $6.7 \%$, 其主要原因是 三峡工程蓄水后水库上游未现大水年, 且 2006、2011 年均为枯水年 (图 2). 在 1990 年以前宜昌站年输沙量 无明显变化趋势, 属于随机变化. 受水利工程拦沙、水土保持工程等因素的综合影响, 1990-2002 年期间年 均输沙量呈递减趋势, 较之 $1950-1989$ 年, 年均输沙量减少了 $23.8 \%$; 三峡工程运用后由于水库拦截大量泥 沙, 2003-2012 年期间该站年均输沙量大幅度减少, 较之 1990- 2002 年, 年均输沙量减少了 $87.8 \%$; 2013 年 后长江上游主要支流溪洛渡、向家坝等水库陆续运用, 2013-2017 年期间该站年输沙量进一步减小, 其值为 1100 万 $\mathrm{t}$,基本接近于 “清水”, 仅为 2003-2012 年期间年均输沙量的 $22.8 \%$.

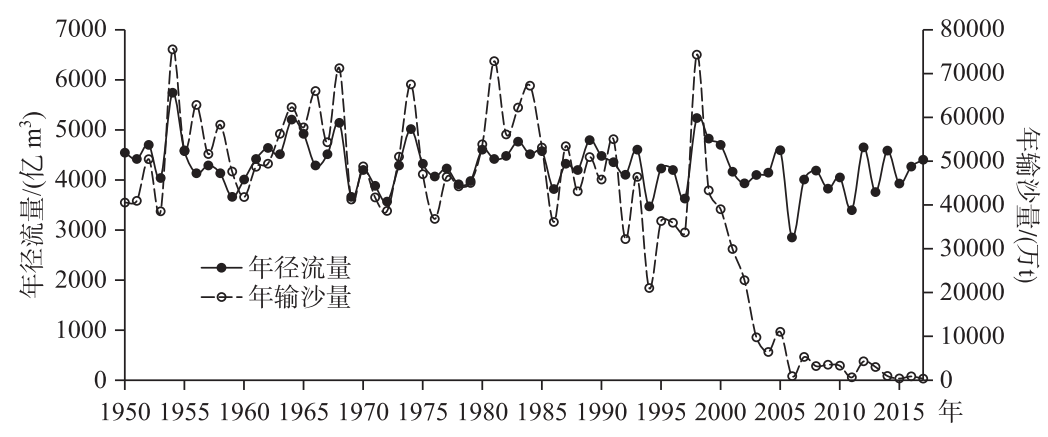

图 2 宜昌站年均径流量、年均输沙量历年变化过程

Fig.2 Annual average runoff and sediment load at Yichang Station

\section{2 坝下游河道河床粗化}

三峡工程运用后, 在 “清水” 冲刷下, 河床将会由上而下逐渐发生粗化. 根据长江水利委员会水文局测量 坝下游河道主要水文站汛后床沙级配的资料, 分析了三峡工程蓄水前、后长江中下游河道主要水文站河床 床沙颗粒级配的变化规律.

由于宜昌站离大坝较近, 三峡水库蓄水后, 该河段首当其冲, 河床粗化明显, 逐步演变为卵石夹沙河床, 床沙中值粒径由 2002 年汛后的 $0.175 \mathrm{~mm}$ 变为 2017 年汛后的 $43.1 \mathrm{~mm}$ ( 图 3a). 由于枝城、沙市、监利站距坝 里程依次增加, 在同一时间上述站点的床沙中值粒径呈减小趋势; 其中蓄水后枝城与沙市站床沙中值粒径 均明显增大, 至 2017 年 10 月份枝城、沙市站床沙 $0.125 \mathrm{~mm}$ 以下的粒径组比重仅分别为 $0.1 \%$ 和 $0.3 \%$; 随着 河床冲刷的影响, 监利站床沙组成呈粗化趋势, 其中 $0.125 \mathrm{~mm}$ 以下粒径组比重不断减小, 由 2003 年 10 月的 $29.8 \%$ 减小至 2017 年 10 月的 $4.7 \%$ (图 3b d). 三峡工程运用后螺山站床沙中值粒径略有增大, 河床 0.125 $\mathrm{mm}$ 以下粒径组比重呈减少趋势, 至 2017 年 10 月本站 $0.125 \mathrm{~mm}$ 以下的粒径组比重仅为 $1.7 \%$, 大通站河床 $0.125 、 0.031 \mathrm{~mm}$ 以下的沙量比重均无明显变化趋势 (图 3e f).

\section{3 江湖入汇沙量变化分析}

下面分析了三峡工程运用后洞庭湖、汉江及鄱阳湖人汇长江年均输沙量变化的规律, 人汇的沙量分别 根据城陵矶、仙桃及湖口站水文资料统计. 三峡工程运用后可分为 2003-2007 年(蓄水初期)、2008-2012 年 (175 m 试验性蓄水期) 及 2013-2017 年(向家坝水库运用后) 3 个阶段 (图 4).

由图 4a 可知, 在以上 3 个阶段, 洞庭湖、汉江及鄱阳湖人汇长江年均输沙量分别呈略有增加、递减与略 有减小的趋势. 近期汉江人汇长江年均输沙量减少的主要原因: 一是汉江流域实施大量水土保持工程, 进人 汉江河道的沙量减少; 二是 “南水北调” 中线工程实施后汉江中下游河道的径流量减少, 进而导致水流挟沙 能力下降; 三是近期汉江中下游河道王甫洲、兴隆等水利枢纽建成运用也导致汉江人汇长江的沙量减少. 图 

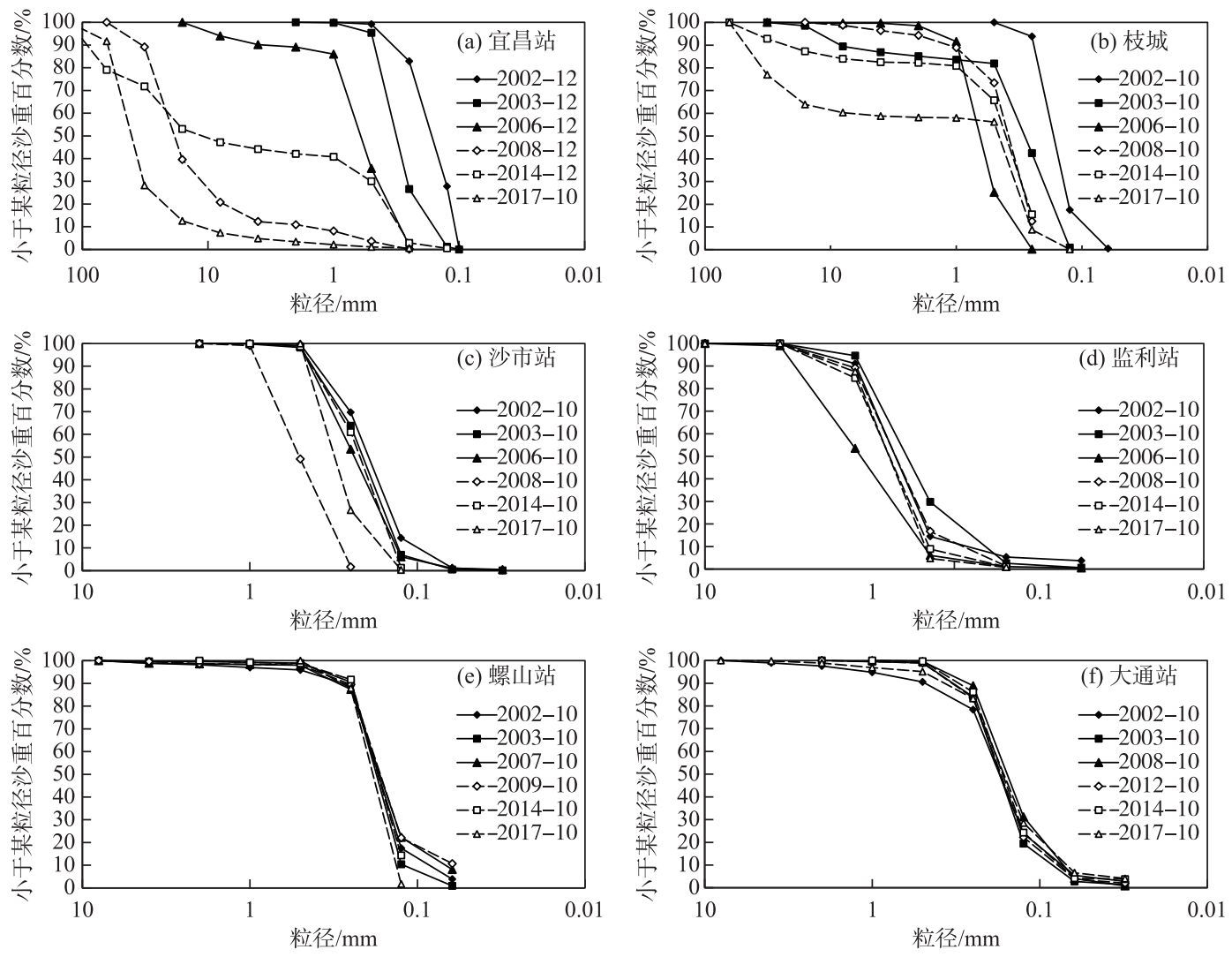

图 3 长江中下游干流河段主要水文站汛后床沙颗粒级配曲线

Fig.3 Variation in the particle grading curves of bed material at the hydrometric stations of the middle and lower reaches of Yangtze River

$4 \mathrm{~b} \sim \mathrm{d}$ 显示, 江湖人汇长江各粒径组年均输沙量与悬沙变化规律基本一致,但两湖 (洞庭湖与鄱阳湖) 人汇长 江主要为 $\mathrm{d} \leqslant 0.031 \mathrm{~mm}$ 的沙量, 而其它粒径组的沙量较少, 其主要原因为荆江“三口”与洞庭湖 “四水” (湘、 资、沅、澧)、鄱阳湖 “五河” (赣江、抚河、信江、饶河、修水) 汇人湖区后, 水体中较粗泥沙颗粒一般均沉积于 湖区, 大部分 $\mathrm{d} \leqslant 0.031 \mathrm{~mm}$ 细颗粒泥沙从湖区人汇长江.

统计了三峡工程运用后不同阶段洞庭湖、汉江及鄱阳湖人汇各粒径组沙量占长江干流相应沙量百分 比, 其中洞庭湖、汉江及鄱阳湖人汇后的长江干流水文站点依次为螺山、汉口及大通, 统计成果如图 5 所示.

在以上 3 个阶段, 洞庭湖人汇各粒径组沙量占长江干流相应沙量百分比呈递增趋势, 其主要原因是螺 山站各粒径组沙量逐渐递减; 汉江人汇各粒径组沙量占长江干流相应沙量百分比呈递减趋势, 这与汉江人 汇长江的沙量大幅减少有关; 鄱阳湖人汇各粒径组沙量占长江干流相应沙量百分比呈递增趋势, 其主要原 因是大通站各粒径组沙量逐渐递减.

\section{4 坝下游河段泥沙输移变化规律}

三峡工程蓄水后,三峡水库下泄沙量大幅度的减少,引起坝下游河道输沙量发生较大调整. 图 6 与表 1 给出了三峡工程运用前、后长江中下游河段主要站点悬移质泥沙年均输沙量的变化情况.

由图 6 与表 1 分析可知,与蓄水前相比,蓄水运用初期(2003-2007 年) 坝下游各主要站点沙量沿程呈 递增趋势, 至大通站年均输沙量未达到蓄水前的水平, 从整体来看, 河床补给与江湖人汇的比值为 $1: 0.84$, 沙量恢复主要受河床补给与江湖人汇共同的影响; 从不同河段来看,监利一汉口河段沙量恢复主要受洞庭湖 

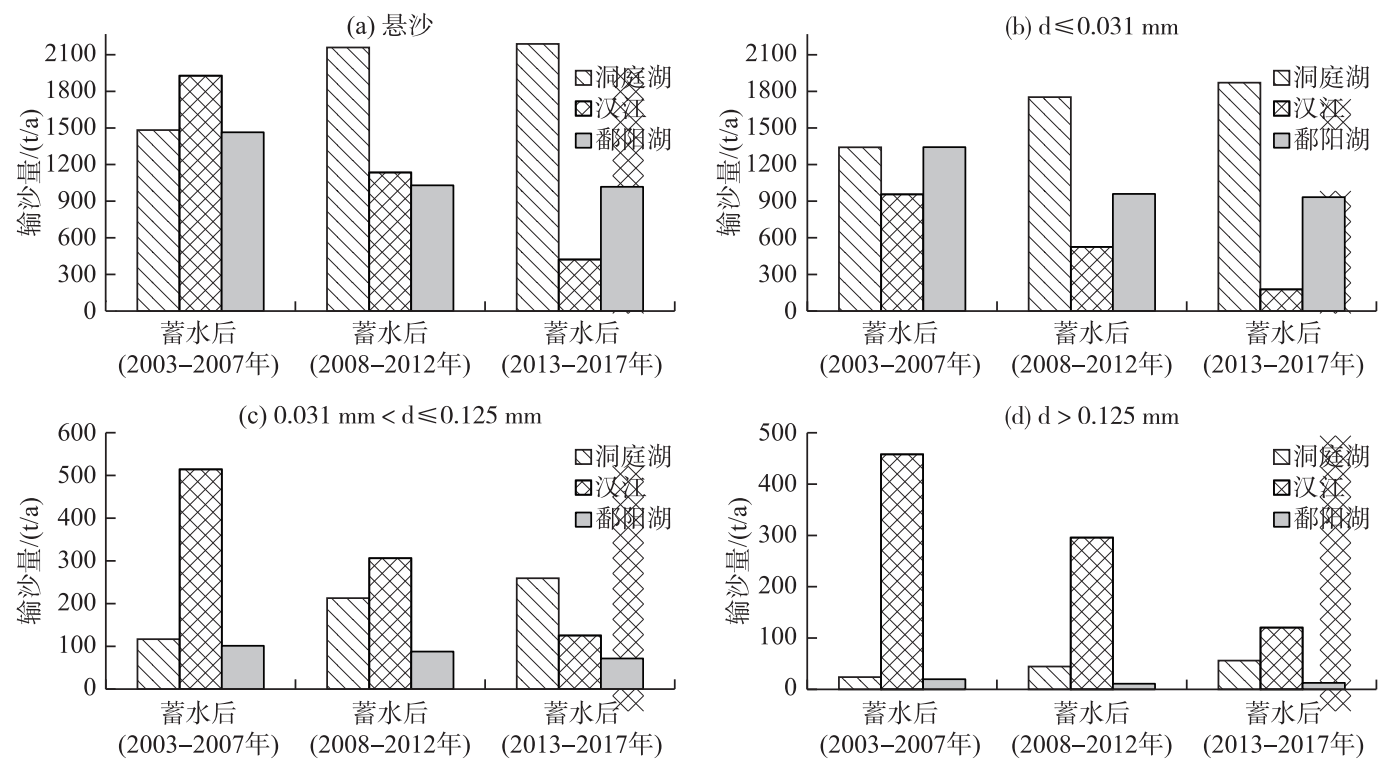

图 4 三峡工程运用后江湖人汇长江年均输沙量变化规律

Fig.4 Temporal variation in sediment transport in the Yangtze River after the operation of the Three Gorges Project

表 1 三峡工程运用后坝下游河床冲淤与 江湖人汇量统计 *

Tab.1 Statistics of river bed scouring and silting and rivers and lakes in the lower reaches of the Three Gorges Project

\begin{tabular}{lccc}
\hline & $\begin{array}{c}2003- \\
2007 \text { 年/ } \\
\text { 河段与江湖 }\end{array}$ & $\begin{array}{c}2008- \\
2012 \text { 年/ } \\
(\text { 万 } \mathrm{t})\end{array}$ & $\begin{array}{c}2013 \text { - } \\
(\text { 年 } \mathrm{t})\end{array}$ \\
\hline 宜昌一监利 & 5007 & 4308 & 3337 \\
监利一螺山 & -294 & -751 & 413 \\
螺山一汉口 & -382 & 829 & 374 \\
汉口一大通 & 1440 & 2266 & 3682 \\
河床补给 & 5771 & 6652 & 7806 \\
洞庭湖 & 1482 & 2158 & 2187 \\
汉江 & 1928 & 1135 & 423 \\
鄱阳湖 & 1464 & 1030 & 1018 \\
江湖人汇 & 4874 & 4323 & 3628 \\
河床补给/江湖人汇比值 & $1: 0.84$ & $1: 0.65$ & $1: 0.46$ \\
\hline
\end{tabular}

*负值表示淤积.
与汉江人汇的影响, 宜昌一监利河段沙量恢复主要 受河床补给的影响, 而汉口一大通河段沙量恢复主 要受河床补给与鄱阳湖人汇共同的影响. 在 $175 \mathrm{~m}$ 试验性蓄水期 (2008-2012 年) 与向家坝水库运用 后 $(2013-2017$ 年), 三峡水库下泄沙量大幅递减, 沙量沿程仍呈递增趋势, 但均未达到蓄水前的水 平; 河床补给与江湖人汇的比值分别为 $1: 0.65$ 与 1 : 0.46 , 沙量恢复主要受河床补给的影响, 但江湖人 汇影响也较大 ; 从不同河段来看, 除在汉口一大通河 段鄱阳湖人汇沙量的影响逐渐减小之外, 其它河段 沙量恢复的主要原因未发生较大改变.

由于洞庭湖与鄱阳湖人汇长江干流主要为 $\mathrm{d} \leqslant$ $0.031 \mathrm{~mm}$ 的泥沙, 在坝下游河段尤其荆江河段床沙 质与冲泻质的分界粒径约为 $0.125 \mathrm{~mm}$,下面以 $\mathrm{d} \leqslant$ $0.031 \mathrm{~mm} 、 0.031 \mathrm{~mm}<\mathrm{d} \leqslant 0.125 \mathrm{~mm}$ 与 $\mathrm{d}>0.125 \mathrm{~mm}$ 粒径组沙量来代表坝下游河道细、中、粗沙, 并根据 实测资料分别统计以上 3 组粒径沙量在三峡工程 运用前、后的沿程变化情况.

图 7a 与表 2 显示, 与蓄水前相比, 蓄水运用初

期坝下游各主要站点 $\mathrm{d} \leqslant 0.031 \mathrm{~mm}$ 年均输沙量沿程呈递增趋势, 至大通站该粒径组沙量未达到蓄水前的水 平; 从整体来看, 河床补给与江湖人汇比值为 $1: 0.86$, 沙量恢复主要受河床补给与江湖人汇共同的影响; 从不 同河段来看, 宜昌一汉口河段沙量恢复主要受洞庭湖与汉江人汇的影响, 汉口一大通河段主要受河床补给的 影响. 在 $175 \mathrm{~m}$ 试验性蓄水期与向家坝水库运用后, 水库下泄该粒径组沙量大幅递减, 沙量沿程递增, 但均 未达到蓄水前的水平, 河床补给与江湖人汇的比值分别为 $1: 0.85$ 与 $1: 0.62$, 说明该粒径组沙量恢复主要受 河床补给与江湖人汇共同的影响. 

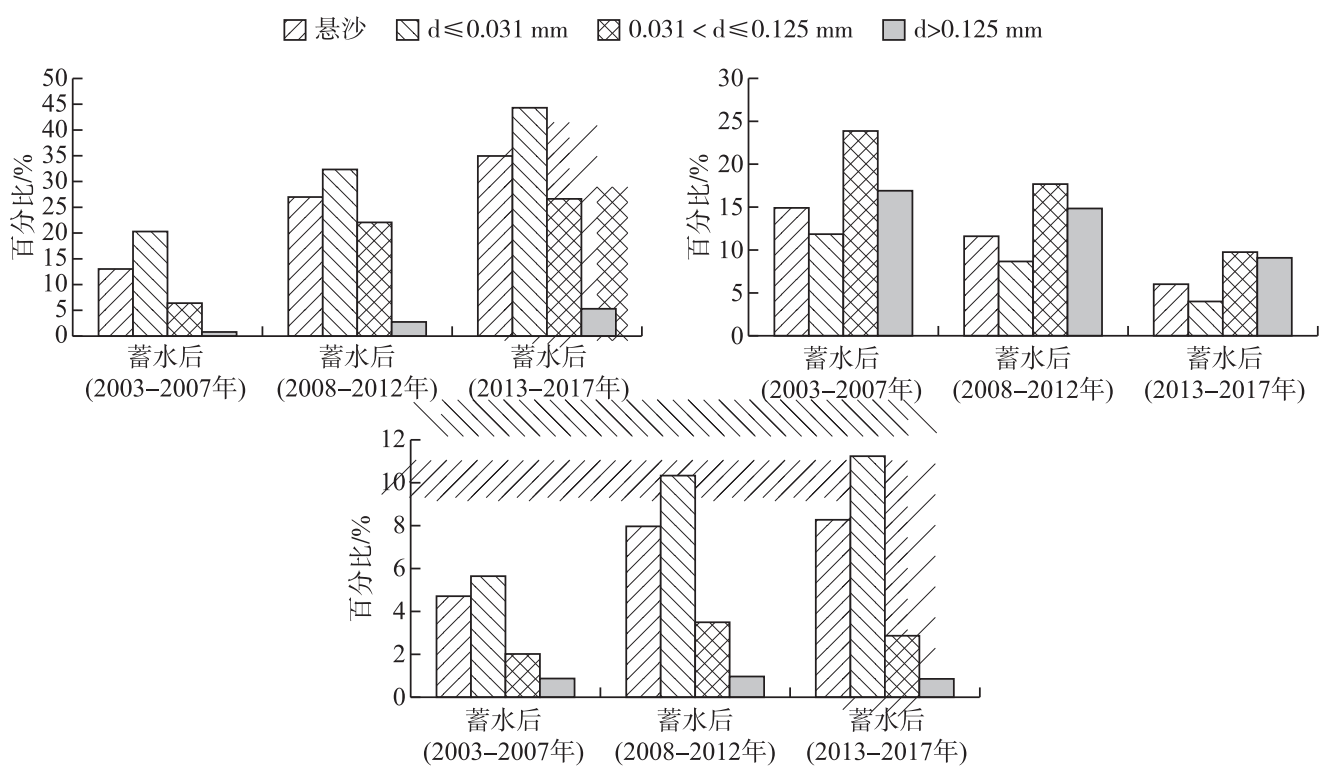

图 5 三峡工程运用后江湖人汇各粒径组沙量占长江干流相应沙量的百分比

Fig.5 The amount of sand in each particle size group of the rivers and lakes accounts for the corresponding amount of sand in the main stream of the Yangtze River after the operation of the Three Gorges Project

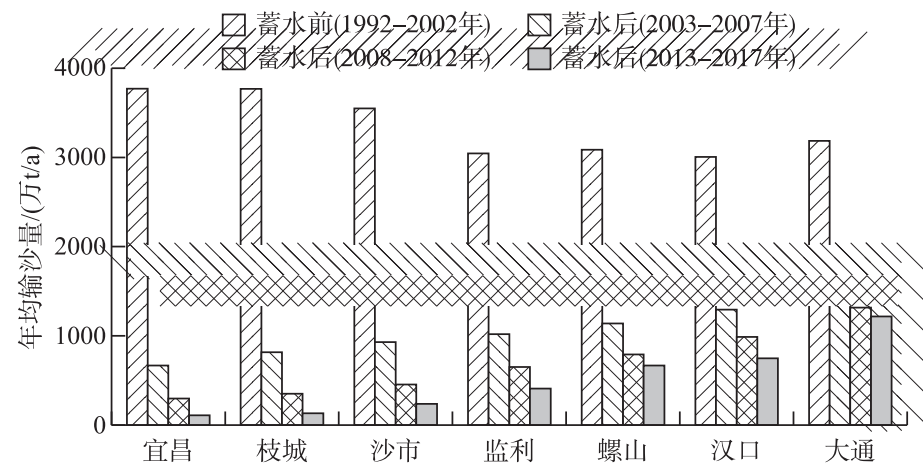

图 6 三峡工程运用前后坝下游河段主要站点年均输沙量变化对比

Fig.6 Comparison of annual average sediment load in the main stations of downstream rivers before and after the onset of the Three Gorges Project

由图 $7 \mathrm{~b}$ 与表 2 可知, 与蓄水前相比, 蓄水运用初期坝下游各主要站点 $0.031 \mathrm{~mm}<\mathrm{d} \leqslant 0.125 \mathrm{~mm}$ 年均输沙 量沿程递增, 至大通站该粒径组沙量未达到蓄水前的水平, 从整体来看, 河床补给与江湖人汇的比值为 1 : 0.50 , 沙量恢复主要受河床补给的影响, 但江湖人汇影响也较大; 从不同河段来看, 除监利一汉口河段沙量恢 复主要受汉江人汇影响外,其它河段沙量恢复主要受河床补给的影响. 在 $175 \mathrm{~m}$ 试验性蓄水期与向家坝水 库运用后, 水库下泄该粒径组沙量大幅递减, 河床补给未明显变化, 沙量沿程递增, 但均未达到蓄水前的水 平, 由于江湖人汇补给明显减少, 河床补给与江湖人汇比值分别为 $1: 0.30 、 1: 0.25$, 说明沙量恢复主要受河床 补给的影响,但江湖人汇的影响逐渐减小.

图 7c 与表 2 显示,与蓄水前相比,蓄水运用初期 $\mathrm{d}>0.125 \mathrm{~mm}$ 沙量在宜昌一监利河段沿程恢复速率较 快, 沙量恢复主要受河床补给的影响, 且在监利站达到蓄水前的水平, 而监利以下河段沙量以淤积为主; 在 $175 \mathrm{~m}$ 试验性蓄水期与向家坝水库运用后, 水库下泄该粒径组沙量递减, 在宜昌一监利河段沙量沿程恢复且 
速率仍较快, 沙量恢复仍主要受宜昌一监利河段河床补给的影响,在监利站达到最大值,而在监利以下河段 以淤积为主; 但随着宜昌一监利河段河床下切, 流速减缓, 河道输沙能力减小, 该粒径沙量恢复逐渐小于蓄水 前的水平.

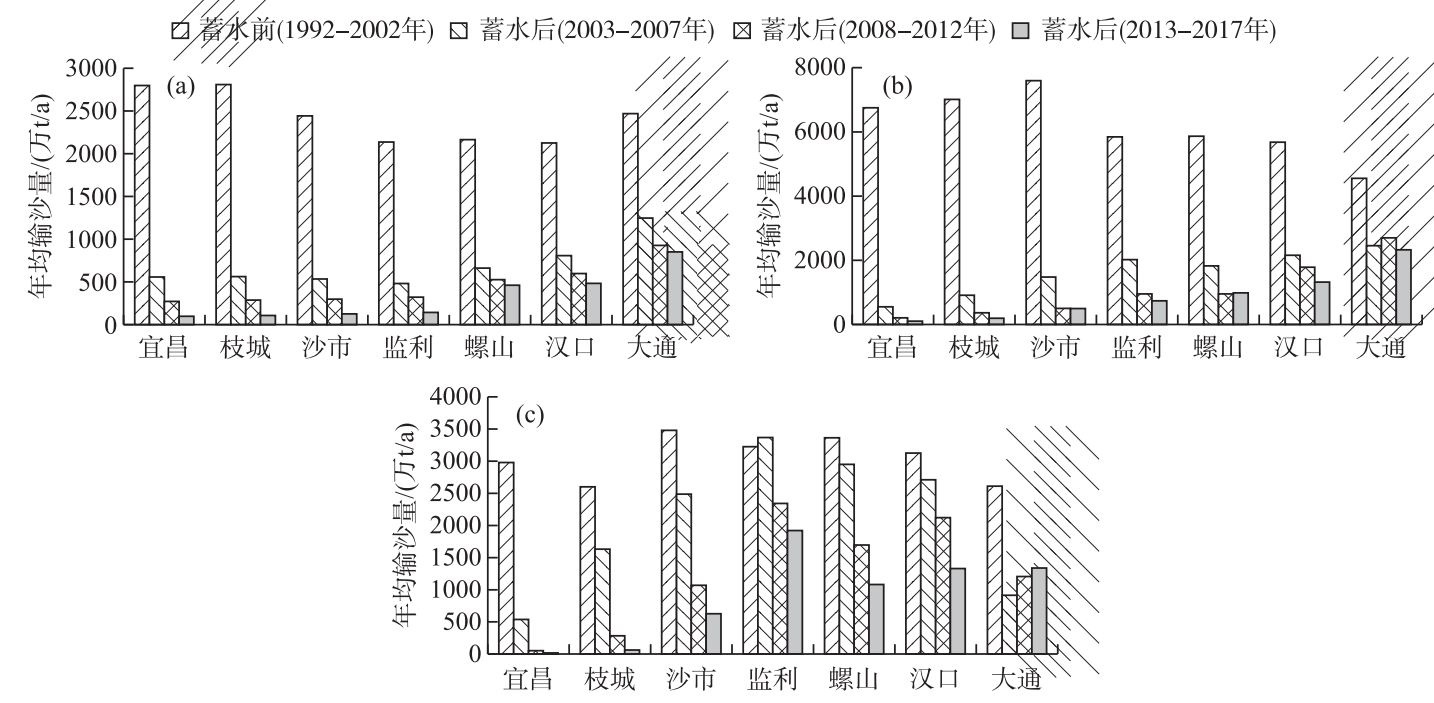

图 7 三峡工程运用前后长江中下游主要站点 $\mathrm{d} \leqslant 0.031 \mathrm{~mm}(\mathrm{a}) 、 0.031 \mathrm{~mm}<\mathrm{d} \leqslant 0.125 \mathrm{~mm}(\mathrm{~b})$ 、 $\mathrm{d}>0.125 \mathrm{~mm}(\mathrm{c})$ 年均输沙量变化对比

Fig.7 Comparison of annual average sediment load volume of $d \leqslant 0.031 \mathrm{~mm}(\mathrm{a}), 0.031 \mathrm{~mm}<\mathrm{d} \leqslant 0.125 \mathrm{~mm}(\mathrm{~b})$, $\mathrm{d}>0.125 \mathrm{~mm}(\mathrm{c})$ in the main stations of downstream rivers before and after the onset of the Three Gorges Project

表 2 三峡工程运用后坝下游 $\mathrm{d} \leqslant 0.031 \mathrm{~mm} 、 0.031 \mathrm{~mm}<\mathrm{d} \leqslant 0.125 \mathrm{~mm} 、 \mathrm{~d}>0.125 \mathrm{~mm}$ 河床冲淤与江湖人汇量统计

Tab.2 Statistics of river bed scouring and silting and rivers and lakes of $d \leqslant 0.031 \mathrm{~mm}$,

$0.031 \mathrm{~mm}<\mathrm{d} \leqslant 0.125 \mathrm{~mm}, \mathrm{~d}>0.125 \mathrm{~mm}$ in the lower reaches of the Three Gorges Project

\begin{tabular}{|c|c|c|c|c|c|c|c|c|c|}
\hline \multirow[b]{2}{*}{ 河段与江湖 } & \multicolumn{3}{|c|}{$\mathrm{d} \leqslant 0.031 \mathrm{~mm}$} & \multicolumn{3}{|c|}{$0.031 \mathrm{~mm}<\mathrm{d} \leqslant 0.125 \mathrm{~mm}$} & \multicolumn{3}{|c|}{$\mathrm{d}>0.125 \mathrm{~mm}$} \\
\hline & $\begin{array}{c}2003- \\
2007 \text { 年/ } \\
(\text { 万 } \mathrm{t})\end{array}$ & $\begin{array}{c}2008- \\
2012 \text { 年/ } \\
(\text { 万 } t)\end{array}$ & $\begin{array}{c}2013- \\
2017 \text { 年/ } \\
(\text { 万 } \mathrm{t})\end{array}$ & $\begin{array}{c}2003- \\
2007 \text { 年/ } \\
(\text { 万 } \mathrm{t})\end{array}$ & $\begin{array}{c}2008- \\
2012 \text { 年/ } \\
(\text { 万 } t)\end{array}$ & $\begin{array}{c}2013- \\
2017 \text { 年/ } \\
(\text { 万 } \mathrm{t})\end{array}$ & $\begin{array}{c}2003- \\
2007 \text { 年/ } \\
(\text { 万 } \mathrm{t})\end{array}$ & $\begin{array}{c}2008- \\
2012 \text { 年/ } \\
(\text { 万 } t)\end{array}$ & $\begin{array}{c}2013- \\
2017 \text { 年/ } \\
(\text { 万 } \mathrm{t})\end{array}$ \\
\hline 宜昌一监利 & 243 & 999 & 665 & 1771 & 918 & 709 & 2994 & 2392 & 1962 \\
\hline 监利一螺山 & 457 & 300 & 1317 & -310 & -212 & -8 & -441 & -691 & -895 \\
\hline 螺山一汉口 & 500 & 180 & 34 & -185 & 527 & 211 & -697 & 130 & 129 \\
\hline 汉口一大通 & 3057 & 2339 & 2755 & 200 & 826 & 932 & -1817 & -926 & -5 \\
\hline 河床补给 & 4257 & 3818 & 4772 & 1476 & 2058 & 1844 & $2994^{*}$ & $2392 *$ & $1962 *$ \\
\hline 洞庭湖 & 1341 & 1753 & 1872 & 117 & 213 & 260 & 24 & 44 & 56 \\
\hline 汉江 & 956 & 525 & 177 & 514 & 306 & 125 & 458 & 296 & 120 \\
\hline 鄱阳湖 & 1343 & 960 & 933 & 101 & 88 & 72 & 20 & 11 & 13 \\
\hline 江湖人汇 & 3640 & 3237 & 2982 & 732 & 607 & 457 & 502 & 351 & 189 \\
\hline 河床补给/江湖人汇比值 & $1: 0.86$ & $1: 0.85$ & $1: 0.62$ & $1: 0.50$ & $1: 0.30$ & $1: 0.25$ & $1: 0.17$ & $1: 0.15$ & $1: 0.10$ \\
\hline
\end{tabular}

* 因 $\mathrm{d}>0.125 \mathrm{~mm}$ 沙量在宜昌一监利河段冲刷, 而监利以下河段一般淤积, 河床补给则用宜昌一监利河段冲刷量代替.

三峡工程运用后, 水库拦截大量泥沙, “清水”下泄, 坝下游河段水流将会长期处于非饱和状态, 尤其随 着上游向家坝、溪洛渡等梯级水库群陆续建成运用后, 水库下泄的沙量更少, 基本接近 “清水”. 在这种冲刷 背景下, 坝下游河道将会长期处于冲刷状态, 由于坝下游河道河床组成的差异性, 越往下游河床组成越细, 河床组成的不同与江湖人汇的影响,坝下游河段不同粒径组沙量恢复距离与程度呈现以下规律: 蓄水初期 $\mathrm{d} \leqslant 0.031 \mathrm{~mm}$ 沙量沿程恢复主要受河床补给与江湖人汇的影响, 随着时间推移, 水库下泄该粒径组沙量递 减, 沙量沿程递增, 但均小于蓄水前的水平, 沙量恢复仍主要受河床补给与江湖人汇的影响; 蓄水初期 
$0.031 \mathrm{~mm}<\mathrm{d} \leqslant 0.125 \mathrm{~mm}$ 沙量恢复主要受河床补给的影响, 江湖人汇的影响也较大, 随着时间推移, 水库下泄 该粒径组沙量递减, 河床补给减少, 该粒径组沙量小于蓄水前的水平, 沙量恢复主要受河床补给的影响, 江 湖人汇的影响逐渐减小; $\mathrm{d}>0.125 \mathrm{~mm}$ 沙量恢复主要受宜昌一监利河段河床补给的影响, 蓄水初期该粒径组 沙量在宜昌一监利河段沿程恢复速率较快, 且在监利站达到蓄水前的水平,随着时间推移, 水库下泄该粒径 组沙量递减, 在宜昌一监利河段沿程恢复且速率仍较快, 在监利站达到最大值, 但其数值逐渐小于蓄水前的 水平.

不同粒径组沙量恢复距离与程度不同, 也导致河床冲刷距离不同, 坝下游河道河床 $\mathrm{d} \leqslant 0.125 \mathrm{~mm}$ 沙量 相对较少, $\mathrm{d} \leqslant 0.031 \mathrm{~mm}$ 与 $0.031 \mathrm{~mm}<\mathrm{d} \leqslant 0.125 \mathrm{~mm}$ 的沙量在宜昌一大通河段受到河床沿程补给, 这是造成 坝下游河道发生长距离冲刷的主要原因; 坝下游河道河床 $\mathrm{d}>0.125 \mathrm{~mm}$ 沙量大量存在, 该粒径组沙量沿程恢 复主要受宜昌一监利河段河床补给的影响,这是造成坝下游冲刷重点集中在宜昌一监利河段的主要原因.

\section{5 结论}

本文根据实测资料分析了三峡水库坝下游泥沙输移变化规律, 探索不同粒径组沙量沿程恢复对坝下游 河道河床冲刷的影响,得到以下结论:

1) 60 多年来宜昌站的年均径流量没有发生明显的趋势性变化,但年均输沙量自 1990 年来呈递减趋势. 三峡工程蓄水后枝城与沙市站汛后床沙中值粒径呈明显增大趋势, 监利站则略有增大, 螺山站河床 0.125 $\mathrm{mm}$ 以下粒径组比值不断减少,大通站河床 $0.125 、 0.031 \mathrm{~mm}$ 以下的沙量比重无明显变化趋势.

2 ) 在蓄水后的 3 个阶段, 洞庭湖人汇长江年均输沙量略有增加, 汉江人汇长江年均输沙量呈递减趋势, 鄱阳湖人汇长江年均输沙量则略有减小, 两湖 (洞庭湖与鄱阳湖) 人汇长江主要为 $\mathrm{d} \leqslant 0.031 \mathrm{~mm}$ 的沙量, 而 其他粒径组沙量很少.

3 ) 蓄水后 $\mathrm{d} \leqslant 0.031 \mathrm{~mm}$ 沙量恢复主要受河床补给与江湖人汇的影响; 蓄水初期 $0.031 \mathrm{~mm}<\mathrm{d} \leqslant 0.125 \mathrm{~mm}$ 沙量沿程恢复主要受河床补给的影响, 但江湖人汇影响也较大, 随着时间推移, 水库下泄该粒径组沙量递 减,该粒径组沙量恢复主要受河床补给的影响,江湖人汇的影响逐渐减小; 蓄水初期 $\mathrm{d}>0.125 \mathrm{~mm}$ 沙量在宜 昌一监利河段沿程恢复速率较快, 且在监利站达到蓄水前的水平, 随着时间推移, 水库下泄该粒径组沙量递 减, 在宜昌一监利河段沿程恢复且速率仍较快, 在监利站达到最大值, 但其值逐渐小于蓄水前的水平.

$4) \mathrm{d} \leqslant 0.031 \mathrm{~mm}$ 和 $0.031 \mathrm{~mm}<\mathrm{d} \leqslant 0.125 \mathrm{~mm}$ 沙量在宜昌一大通河段受到河床沿程补给, 这是造成坝下游 河道发生长距离冲刷的主要原因; $\mathrm{d}>0.125 \mathrm{~mm}$ 沙量沿程恢复主要受宜昌一监利河段河床补给的影响, 这是 造成坝下游冲刷重点集中在宜昌一监利河段的主要原因.

\section{6 参考文献}

[ 1 ] Qian N ed. River morphology. Beijing: Science Press, 1987.[ 钱宁. 河床演变学. 北京: 科学出版社, 1987.]

[ 2 ] Xie JH ed. River bed evolution and regulation. Wuhan: Wuhan University Press, 2013. [谢鉴衡. 河床演变及整治. 武 汉: 武汉大学出版社, 2013.]

[ 3 ] Han QW. Theoretical study ofnonequililrium transportation of nonuniform suspended load. Water Resources and Hydropower Engineering, 2007, 38(1): 14-23. [韩其为. 非均匀沙不平衡输沙的理论研究. 水利水电技术, 2007, 38(1): 14-23.]

[ 4 ] Li YT. Degradation in river channels downstream from the reservoirs. Journal of Sediment Research, 1994, (2): 77-84. [李义天. 水库下游河道冲刷机理探讨. 泥沙研究, 1994, (2) : 77-84.]

[ 5 ] Yao SM, Lu JY. Research on water and sediment transport characteristics downstream the Three Gorges reservoir before and after its impoundment. Journal of Hydroelectric Engineering, 2011, 30(3): 117-123. [姚仕明, 卢金友. 三峡水库蓄水 运用前后坝下游水沙输移特性研究. 水力发电学报, 2011, 30(3): 117-123.]

[ 6 ] Liu C, Sui JY, He Y et al. Changes in runoff and sediment load from major Chinese rivers to the Pacific Ocean over the period 1955-2010. International Journal of Sediment Research, 2013, 28(4) : 486-495.

[ 7 ] Xu QX. Research on reservoir sedimentation and downstream channel erosion of dam after impoundment of Three Gorges Reservoir. Yangtze River, 2012, 43(7): 1-6. [许全喜. 三峡水库蓄水以来水库淤积和坝下冲刷研究. 人民长江, 
$2012, \mathbf{4 3}(7): 1-6$.

[ 8 ] Han QW ed. Reservoir sedimentation. Beijing: Science Press, 2003. [ 韩其为. 水库淤积. 北京: 科学出版社, 2003. ]

[ 9 ] Li YT, Sun ZH, Deng JY. A study on riverbed erosion downstream from the Three Gorges Reservoir. Journal of Basic Science and Engineering, 2003, 11(3) : 283-295. [李义天, 孙昭华, 邓金运. 论三峡水库下游的河床冲淤变化. 应用基 础与工程科学学报, $2003, \mathbf{1 1}(3): 283-295$.]

[10] Chen JG, Zhou WH, Yuan YP. Transportation and adjustment of different grain sized sediment along the lower Yellow River under Typical Operation Modes of Sanmenxia Reservoir. Journal of Sediment Research, 2002, (2) : 15-22. [ 陈建国, 周 文浩, 袁玉萍. 三门峡水库典型运用时段黄河下游粗细泥沙的输移和调整规律. 泥沙研究, 2002, (2) : 15-22.]

[11] Chen F, Li YT, Tang JW et al. Analysis of group-sized sediment transport downstream a reservoir. Journal of Hydroelectric Engineering, 2010, 9(1): 164-170. [ 陈飞, 李义天, 唐金武等. 水库下游分组沙冲淤特性分析. 水力发电学报, 2010, 9(1): 164-170.]

[12] Guo XH, Li YT, Qu G et al. Analysis of sediment transport in Middle Yangtze River after filling of the Three Gorges Reservoir. Journal of Sediment Research, 2014, (5): 11-17. [ 郭小虎, 李义天, 渠庚等. 三峡工程蓄水后长江中游泥沙输 移规律分析. 泥沙研究, 2014, (5): 11-17.]

[13] Yang YP, Zhang MJ, Li SZ et al. Transport patterns of the coarse and fine sediments and its causes in the downstream of the Three Gorges Dam. J Lake Sci, 2017, 29(4) : 942-954. DOI: 10.18307/2017.0418. [杨云平, 张明进, 李松喆等. 三峡大坝下游粗细颗粒泥沙输移规律及成因. 湖泊科学, 2017, 29(4) : 942-954.] 